\title{
Characterization of Rice (Oryza sativa L.) Physiological Responses to $\alpha$-Tocopherol, Glycine Betaine or Salicylic Acid Application
}

\author{
Abdul Razack Mohammed (Corresponding author) \\ Texas AgriLife Research and Extension Center \\ 1509 Aggie Drive, Beaumont, Texas 77713, USA \\ Tel: 1-409-752-2741 ext 2319 E-mail: abdulrazack@neo.tamu.edu \\ Lee Tarpley \\ Texas AgriLife Research and Extension Center \\ 1509 Aggie Drive, Beaumont, Texas 77713, USA \\ Tel: 1-409-752-2741 ext 2235 E-mail: 1tarpley@tamu.edu
}

\begin{abstract}
The impacts of $\alpha$-tocopherol, glycine betaine (GB) and salicylic acid (SA) applications on higher plants have been the subject of many studies, with special emphasis on oxidative stress tolerance under adverse conditions. However, little work has been carried out on rice responses to $\alpha$-tocopherol, GB or SA under non-stress conditions, in which yield could potentially increased. This study determined the effects of $\alpha$-tocopherol (2.3 kg $\left.\mathrm{ha}^{-1}\right)$, GB (2.0 $\left.\mathrm{kg} \mathrm{ha}^{-1}\right)$ or SA (12.9 $\mathrm{g} \mathrm{ha}^{-1}$ ) application on rice morphology, phenology and physiology under non-stress conditions. The applications did not affect production of tillers, biomass, phenology, or pollen germination; however, plant height, leaf characteristics and physiology, spikelet fertility (SF), panicle and grain characteristics and yield were affected. Plants treated with $\alpha$-tocopherol, GB or SA showed 6\%, 13\% and 13.5\% increases in grain yield as a result of decreased respiration and increased membrane integrity and SF.
\end{abstract}

Keywords: $\alpha$-Tocopherol, Glycine betaine, Grain characteristics, Rice, Rice physiology, Salicylic acid

\section{Introduction}

Plants exposed to environmental stresses, such as heat, cold, drought and salinity, produce ROS, which damage macromolecules and cell membranes (Zhang \& Kirkham, 1996). Angiosperms possess several enzymatic and non-enzymatic scavenging systems to minimize deleterious effects of ROS. These include lipid-soluble antioxidants (e.g. $\alpha$-tocopherol and $\beta$-carotene), water-soluble reactants (e.g. ascorbic acid and glutathione), and enzymatic antioxidants (e.g. superoxide dismutase, catalase and enzymes of the ascorbate and glutathione cycles) (Zhang \& Kirkham, 1996). Salicylic acid (SA) and glycinebetaine (GB) are synthesized in plants and provide important but different, roles in preventing oxidative damage to the membranes (Bowler et al., 1992; Bohnert \& Jensen, 1996; Demiral \& Turkman, 2004; Larkindale \& Huang, 2004).

Alpha-tocopherol is a small molecule that is synthesized in the plants, mainly concentrated in plastids, and is one of the most effective single-oxygen quenchers (Fryer, 1992). Tolerance to salt stress, chilling stress, UV-B stress and pollutant stress is partly correlated with tocopherol content (Munné-Bosch \& Alegre, 2002). Alpha-tocopherol is a strong antioxidant that assists in maintaining membrane stability (Munné-Bosch \& Falk, 2004), intracellular signaling, and transport of electrons in the photosystem-II system (Munné-Bosch \& Alegre, 2002) and is photoprotective in nature.

Glycine betaine is an important osmoprotectant and an amino-acid derivative that is synthesized in many plant families including Chenopodiaceae, Amaranthaceae, Gramineae, Compositae and Malvaceae (Rhodes \& Hanson, 1993; Demiral \& Turkman, 2004). It enhances tolerance to high temperatures (Paleg et al., 1981), low temperatures (Farooq et al., 2008a), freezing temperatures (WeiBing and Rajashekar, 2001), drought stress (Måkela et al., 2000) and salinity (Harinasut et al., 1996; Rahman et al., 2002). Glycine betaine induces tolerance by protecting the Rubisco enzyme (Paleg et al., 1981) and photosystem II (Allakhverdiev et al., 1996), maintaining turgor pressure (Wyn Jones, 1984) and ion homeostasis, and through alteration of parts of signal transduction (Ashraf \& Foolad, 2007). Plants under various stress conditions showed improvement in growth, 
survival, leaf water potential, ion uptake and stress tolerance due to exogenous application of GB (Diaz-Zorita et al., 2001).

Salicylic acid, a phenolic compound, is associated with stress tolerance in plants. Previous studies report that SA can induce tolerance against high and low temperatures, drought, salinity, ultraviolet light, heavy metal toxicity, diseases and pathogens (Raskin, 1992; Yalpani et al., 1994; Dat et al., 1998; Metwally et al., 2003; Sakhabutdinova et al., 2003; Hayat \& Ahmad, 2007; Horváth et al., 2007, Farooq et al., 2008b; Hussain et al., 2008). In addition, SA plays an essential role in preventing oxidative damage in plants by detoxifying superoxide radicals (Bowler et al., 1992) and is also involved in calcium signaling (Kawano et al., 1998). Plants treated with SA showed increased vigor of early seedling growth (Farooq et al., 2008b), increased photosynthetic rates and water use efficiency, and decreased stomatal conductance and transpiration rate (Khan et al., 2010). Moreover, there is evidence that exogenous application of SA can alter antioxidant capacity in plants (Rao et al., 1997), thereby providing protection against oxidative damage (Larkindale \& Huang 2004), thereby inducing stress tolerance.

Alpha-tocopherol, GB and SA - the chemicals used in this study - are all important in plant growth and development and are also associated with stress tolerance in plants. Plants pre-treated with $\alpha$-tocopherol (Fryer, 1992), GB (Diaz-Zorita et al., 2001), or SA (Larkindale \& Knight, 2002) showed induced stress tolerance and protection against oxidative damage due to various stresses. Despite the importance of these chemicals in stress tolerance, little is known about their effects on rice morphology, phenology and physiology. The research presented herein addresses the effects of $\alpha$-tocopherol, GB or SA on rice morphology, phenology and physiology, under non-stress conditions.

\section{Materials and Methods}

\subsection{Plant culture}

Two experiments were conducted in the greenhouse at the Texas AgriLife Research and Extension Center at Beaumont, Texas, USA. 'Cocodrie', a common tropical japonica-type U.S. rice cultivar, was used in both the experiments. Plants were grown in $3 \mathrm{~L}$ pots that were placed in a square box $\left(0.84 \mathrm{~m}^{2}\right), 10$ pots per box. The boxes were lined with black plastic (thickness $=6.0 \mathrm{~mm}$; FILM-GARD, Minneapolis, Minnesota, USA) that served as a water reservoir. Pots were filled with a clay-rich soil that is common to rice farms in the area. At 20 days after emergence (DAE), the boxes were filled with water to approximately $3 \mathrm{~cm}$ above the top of the soil in each pot. A three-way split application of nitrogen was performed as described by Mohammed et al., (2007) in both the experiments. Nitrogen was applied in the form of urea and ammonium sulfate, and phosphorus in the form of $\mathrm{P}_{2} \mathrm{O}_{5}$. Nitrogen was applied at the rate of $113.5 \mathrm{~kg} \mathrm{ha}^{-1}$ along with $45.4 \mathrm{~kg} \mathrm{ha}^{-1}$ of phosphorus $\left(\mathrm{P}_{2} \mathrm{O}_{5}\right)$ at planting. The remaining nitrogen fertilizations (both $79.5 \mathrm{~kg} \mathrm{ha}^{-1}$ of nitrogen in the form of ammonium sulfate) were applied $20 \mathrm{DAE}$ and at the panicle-differentiation stage. Mean day temperature and humidity were monitored independently of the controlled experimental temperatures using standalone sensor/loggers (HOBOs, Onset Computer Corporation, Bourne, Massachusetts, USA). The mean day temperatures and absolute humidity in the greenhouse ranged between $27-35{ }^{\circ} \mathrm{C}$ and $13-14 \mathrm{~g} / \mathrm{m}^{3}$, respectively. The light intensity and $\mathrm{CO}_{2}$ in the greenhouse during the day were measured using a light quantum meter (Quantum Meter, Apogee Instruments, Logan, Utah, USA) and LI-6400 (LI-6400, LI-COR Inc., Lincoln, Nebraska, USA), respectively. The light intensity and $\mathrm{CO}_{2}$ concentration in the greenhouse ranged between $600-800 \mu \mathrm{mol} \mathrm{m}^{-2} \mathrm{~s}^{-1}$ and $360-380 \mathrm{ppm}$, respectively, depending upon the time of the day.

\subsection{Chemical treatments}

The $\alpha$-tocopherol was applied at the rate of $2.3 \mathrm{~kg} \mathrm{a.i.} \mathrm{ha}^{-1}(2.5 \% \mathrm{v} / \mathrm{v})$; GB was applied at the rate of $2.0 \mathrm{~kg} \mathrm{ha}^{-1}(580$ $\mathrm{mM})$, and SA at the rate of $12.9 \mathrm{~g} \mathrm{ha}^{-1}(1 \mathrm{mM})$. The chemicals were applied at the rate of $100 \mu \mathrm{L}$ per application to the leaves using a pre-calibrated perfume-bottle sprayer. Each plant was treated three times (on a single day; 20 DAE) to enable thorough coverage prior to imposing heat stress, for a total $300 \mathrm{~L}$ per treatment. All the chemicals were dissolved in de-ionized water with $0.5 \%(\mathrm{v} / \mathrm{v})$ surfactant (Latron AG-98 spreader activator, Rohm and Haas Company, Philadelphia, Pennsylvania USA). The $\alpha$-tocopherol and SA were purchased from Sigma-Aldrich (St. Louis, Missouri, USA). The GB was supplied by Capstone Food Ingredients (Marion, Massachusetts, USA).

\subsection{Growth and development}

Plant height (from base of the stem to tip of the uppermost-reaching leaf) and the numbers of productive tillers were recorded at harvest. Daily observations were made for the appearance of panicles. The number of leaves was counted at the early grain-fill stage (EGF), the individual penultimate leaf length (from the point of contact of the leaf blade and the stem to the tip of the leaf) and leaf breadth (widest part of the leaf) was also measured at EGF 
stage. The final harvest was carried out at 100 DAE. Destructive sampling procedures were adopted: plants were dissected, productive tillers were counted, plant height and leaf areas were measured, and dry weights were determined. Leaf area was measured using a CI-251 area meter (CID Inc., Camas, Washington, USA). In this study, biomass per plant was calculated by summing up the values of stem dry weight, leaf dry weight and root dry weight of the individual plant.

\subsection{Pollen germination}

The percent pollen germination (PPG) was determined through in vitro germination on a culture medium. The culture medium was prepared in accordance with the media of Song et al., (2001), with minor modifications. The components of the culture medium in the present study were $15 \mathrm{~g}$ sucrose, $0.03 \mathrm{~g}$ calcium nitrate, and $0.01 \mathrm{~g}$ boric acid dissolved in $100 \mathrm{ml}$ deionised water. Agar, $0.06 \mathrm{~g}$, was added to this solution, which was heated on a hot plate to dissolve the agar. When the agar was dissolved in the solution, $10 \mathrm{ml}$ medium was poured per Petri dish (diameter $8.5 \mathrm{~cm}$ ) and allowed to cool for 15 minutes. The pollen from different treatments was dusted on this medium as soon as the floret opened in the morning. Pollen was dusted on Petri dishes and incubated at $27{ }^{\circ} \mathrm{C}$ for 24 hours in the dark. Pollen was considered as germinated when the pollen tube length was at least equal to the grain diameter as determined using a microscope. The total numbers of pollen grains, germinated and non-germinated pollen in each Petri dish were counted, and the PPG was recorded.

\subsection{Spikelet fertility $(S F)$, panicle and grain characteristics}

The main-stem panicles were tagged at panicle emergence and harvested at physiological maturity separately from the tiller panicles. The main-stem panicle length, number of primary branches, total grain number, filled grain number and unfilled grain number per panicle were determined at harvest. Spikelet fertility was defined as the ratio of filled grains to total number of grains in the panicle. Each floret was pressed between the thumb and forefinger to determine if the grain was filled or not. Spikelet fertility was expressed as percentage.

Main-stem panicle length and number of primary branches on the panicle were recorded. In both experiments, grain length and width of brown (dehulled) rice were determined using a Winseedle (Regent Instruments, Inc. Quebec, Canada), which uses image analysis of scanned color images of the grain to calculate these parameters. Ten grains per replication were used to determine grain length, width and chalkiness. The weight of 100 filled-grains (dehulled grain) was also determined.

\subsection{Leaf photosynthesis}

Leaf net photosynthetic rates $\left(P_{n}\right)$ were measured at the early grain-fill (EGF) stage. The $P_{n}$ was measured on the penultimate leaves using a LI-6400 portable photosynthesis system (LI-COR Inc., Lincoln, Nebraska, USA) between $1000 \mathrm{~h}$ and $1200 \mathrm{~h}$. Three leaves per replication were used to measure $P_{n}$. When measuring $P_{n}$, the photosynthetic photon flux density (PPFD), provided by a 6400-02 LED light source, was set to $1500 \mu \mathrm{mol} \mathrm{m}^{-2}$ $\mathrm{s}^{-1}$. The temperature and $\mathrm{CO}_{2}$ concentration in the leaf cuvette were set to $25^{\circ} \mathrm{C}$ and $360 \mathrm{ppm}\left(\right.$ ambient $\mathrm{CO}_{2}$ concentration in the greenhouse), respectively.

\subsection{Leaf total chlorophyll content}

Chlorophyll was determined on the penultimate leaves at the EGF stage. Three leaf discs $\left(0.196 \mathrm{~cm}^{2}\right.$ each) were obtained from mid-blade while avoiding the mid-vein and placed in a vial $(2.5-\mathrm{ml})$ with 1 -ml dimethyl sulphoxide (DMSO) and incubated at room temperature for $24 \mathrm{~h}$ in darkness to allow for complete extraction of chlorophyll into the solution. The absorbance of the extract was measured in microtiter plates of polypropylene material using a PowerWave microplate spectrophotometer (Bio-Tek Instruments, Inc., Winooski, Vermont, USA) at 648 and $664 \mathrm{~nm}$ to calculate the chlorophyll a and chlorophyll b concentrations (Chappelle et al., 1992). Using the method of Chappelle et al., (1992), which utilizes a DMSO extraction, the concentrations of the pigments were calculated from the absorbance values at 648 and $664 \mathrm{~nm}$ using equations described by Lichtenthaler (1987). The pigment concentrations were expressed on a leaf area basis, $\mu \mathrm{g} \mathrm{cm}^{-2}$. Total chlorophyll was calculated by summing up the values of chlorophyll a and chlorophyll $b$.

\subsection{Leaf nitrogen content ( $\mathrm{LNC}$ ) and grain nitrogen content (GNC)}

For both LNC and GNC, N was measured using an FP-528 Nitrogen/Protein analyzer (LECO Corporation, St. Joseph, Michigan, USA). For LNC analysis, the penultimate leaf was harvested at EGF stage. Leaf nitrogen content was expressed as percentage $(\% ; \mathrm{w} / \mathrm{w})$ and $\mathrm{GNC}$ was expressed as $\mathrm{mg} \mathrm{g}^{-1}$.

\subsection{Leaf respiration rates}

Leaf-level respiration was measured using an LI-6400 portable photosynthesis system (LI-COR Inc., Lincoln, Nebraska, USA). Respiration was measured on the penultimate leaf during the EGF stage. Three leaves per 
replication were used to measure leaf respiration rates. The area of the LI-6400 chamber was set to $6 \mathrm{~cm}^{2}$ and the middle portion of the leaf was preferred for use while measuring respiration rates. While measuring respiration rates, the photosynthetic photon flux density (PPFD) was set at $0 \mu \mathrm{mol} \mathrm{m}^{-2} \mathrm{~s}^{-1}$ (dark environment). The temperature and $\mathrm{CO}_{2}$ concentration in the leaf cuvette were set at $25^{\circ} \mathrm{C}$ and $360 \mu \mathrm{mol}$, respectively. Respiration was measured during the nighttime between $2300 \mathrm{~h}$ and $0002 \mathrm{~h}$.

\subsection{Leaf membrane thermal stability}

Leaves were harvested at EGF stage for the leaf membrane thermal stability assay. The leaf membrane thermal stability of leaves was measured using the procedure described by Martineau et al., (1979). Each sample assay consisted of two sets of five leaf discs cut with a 1-cm diameter punch from the penultimate leaves. The sets were placed into two separate test tubes with $10-\mathrm{mL}$ de-ionized water, after rinsing them three or four times with de-ionized water. One set of test tubes was submerged in a water bath at $55^{\circ} \mathrm{C}$ for 20 minutes to a depth equal to the height of water in the tubes. The other set of test tubes was held at room temperature $\left(25^{\circ} \mathrm{C}\right)$. After that, both sets of test tubes were incubated at $10{ }^{\circ} \mathrm{C}$ for $12 \mathrm{~h}$. Conductance was measured using a conductivity meter (SensION5 Conductivity Meter, Hach Company, Loveland, Colorado, USA) after standardizing with standard $\mathrm{KCl}$ solutions. Test tubes were then autoclaved for $20 \mathrm{~min}$ at $120^{\circ} \mathrm{C}$ at $0.15 \mathrm{Mpa}$ and conductance was measured again as an indication of maximum potential leakage from a given sample (Ibrahim \& Quick, 2001). The relative injury (RI) was calculated using the equation $\mathrm{RI}=\left(1-\left[1-\left(\mathrm{C}_{55, \mathrm{i}} / \mathrm{C}_{55, \mathrm{f}}\right)\right] /\left[1-\left(\mathrm{C}_{25, \mathrm{i}} / \mathrm{C}_{25, \mathrm{f}}\right)\right]\right) * 100$ where $\mathrm{C}_{55}$ and $\mathrm{C}_{25}$ refer to the conductance at $55^{\circ} \mathrm{C}$ and $25^{\circ} \mathrm{C}$, and the subscript ' $\mathrm{i}$ ' and ' $\mathrm{f}$ ' refers to the initial and final conductance.

\subsection{Total antioxidant capacity of leaf}

Total antioxidant capacity of the rice leaf was measured using the procedures (DPPH [2,2-diphenyl-1-picrylhydrazyl] assay) from Goffman \& Bergman (2004) with modifications. For the DPPH assay, five leaf discs $\left(0.0785 \mathrm{~cm}^{2}\right.$ each $)$ were obtained from mid-blade while avoiding the mid-vein, and their weights recorded. Leaf discs were placed in a test tube (4-ml) with $1.5-\mathrm{ml}$ methyl alcohol $(\mathrm{MeOH})$ then sealed. The test tubes were incubated at room temperature for $24 \mathrm{~h}$ in darkness to allow for complete extraction of antioxidants into the solution. Rice leaf extract of $40 \mu \mathrm{l}$ was added to $960 \mu \mathrm{l}$ DPPH (80 ppm) solution and the optical density determined at $515 \mathrm{~nm}$ after $4 \mathrm{~h}$. The antiradical efficiency of the rice leaf methanolic extracts was determined after $4 \mathrm{~h}$ by monitoring the reduction in the absorbance $(515 \mathrm{~nm})$ of the methanolic solution of DPPH with the extract. The values of DPPH after adding the extract was compared with those obtained from a blank solution of DPPH (zero antiradical activity). Trolox (6-Hydroxyl-2,5,7,8-tetramethylchroman-2-carboxylic acid) and DPPH standard curves were developed and the values were expressed in $\mu$ mol trolox equivalents (TE) $\mathrm{g}^{-1}$ leaf (fresh weight basis) using these standard curves. The DPPH and trolox were purchased from Sigma-Aldrich (St. Louis, MO). Total antioxidant capacity was measured at mid-dough stage of the rice plant.

\subsection{Experimental design and data analysis}

The experiments were laid out in a complete randomized design, and were repeated twice. In each experiment, there were 20 plants, five plants per chemical treatment. To test the significance of experiments, the chemical treatments, and their interactive effects on growth, development and physiology parameters, the data was statistically analyzed using analysis of variance (ANOVA; SAS statistical analysis package version 9.2, SAS Institute, Cary, North Carolina, USA). The means were separated using Tukey's Least Significant Difference (LSD) at an alpha level of 0.05 . If there was no significant difference between the experiments for a parameter, then the values from both the experiments for that parameter (e.g., $n=10$ ) were used to obtain the mean and error. The standard errors of the mean were also calculated and presented in the graphs as error bars.

\section{Results}

\subsection{Effects of $\alpha$-tocopherol, GB or SA on rice morphology, phenology and physiology}

There were no differences among the experiments or for any interaction among the experiments and chemical treatments for the studied variables (Table 1). In addition, application of $\alpha$-tocopherol, GB or SA application did not affect the number of productive tillers per plant, days for $1^{\text {st }}$ panicle emergence, pollen germination or biomass per plant (Table 1). However, plant height, leaf characteristics, leaf physiology, spikelet fertility, grain characteristics and grain yield of rice plants were affected (Table 1).

\subsection{Effects of $\alpha$-tocopherol, GB or SA on plant height, spikelet fertility and grain yield}

There were no significant differences among untreated plants, $\alpha$-tocopherol-treated plants and SA-treated plants with respect to plant height. However, GB-treated plants were 5\% shorter than the untreated plants (Table 2). There was no significant difference between untreated plants and $\alpha$-tocopherol-treated plants with respect to SF. However, GB-treated plants and SA-treated plants showed $14 \%$ and $18 \%$ increase in SF, respectively, compared 
to untreated plants (Table 2). There was no significant difference between untreated plants and $\alpha$-tocopherol-treated plants with respect to grain yield. However, GB-treated plants and SA-treated plants showed $13 \%$ and $13.5 \%$ increase in grain yield, respectively, compared to untreated plants (Table 2).

\subsection{Effects of $\alpha$-tocopherol, GB or SA on leaf characteristics}

Application of $\alpha$-tocopherol, GB or SA affected the number of viable leaves per plant at EGF stage, viable leaf area per plant at harvest, penultimate leaf total chlorophyll content and penultimate leaf nitrogen content measured at EGF stage. However, penultimate leaf length and leaf width measured at EGF stage, were not affected as a result of $\alpha$-tocopherol, GB or SA application. There was no significant difference among untreated plants, GB-treated plants and SA-treated plants with respect to leaf number per plant. However, $\alpha$-tocopherol-treated plants showed $11 \%$ increase in number of leaves per plant compared to untreated plants (Fig. 1). Plants treated with $\alpha$-tocopherol showed 10\% decrease and SA-treated plants showed $11 \%$ increase in penultimate leaf total chlorophyll content measured at EGF stage, compared to untreated plants (Fig. 1). Plants treated with $\alpha$-tocopherol, GB and SA showed $22 \%, 21 \%$ and $28 \%$ increase in penultimate leaf nitrogen content measured at EGF stage, compared to untreated plants (Fig. 1).

\subsection{Effects of $\alpha$-tocopherol, GB or SA on leaf physiology}

There were no significant differences among untreated plants, $\alpha$-tocopherol-, GB- and SA-treated plants with respect to leaf photosynthetic rates, stomatal conductance and leaf total antioxidant capacity (Fig. 2). Plants treated with $\alpha$-tocopherol, GB and SA showed $34 \%, 43 \%$ and $62 \%, 19 \%, 18 \%$ and $31 \%$ and $45 \%, 55 \%$ and $48 \%$ decrease in loss of carbon, leaf transpiration rates and leaf membrane injury measured at EGF stage, respectively, compared to untreated plants (Fig. 2). Plants treated with $\alpha$-tocopherol and SA showed $18 \%$ and $30 \%$ decrease in internal $\mathrm{CO}_{2}$ concentration measured at EGF, compared to untreated plants (Fig. 2). In addition, plants treated with $\alpha$-tocopherol, GB and SA showed 38\%, 50\% and 56\% increase in water use efficiency, compared to untreated plants (Fig. 2).

\subsection{Effects of $\alpha$-tocopherol, GB or SA on main stem panicle and grain characteristics}

There were no significant differences among untreated plants, $\alpha$-tocopherol-, GB- and SA-treated plants with respect to panicle length, number of primary branches per panicle and total grains per panicle (Table 3). However, plants treated with $\alpha$-tocopherol, GB and SA showed $16 \%, 22 \%$ and $32 \%$ increase in the number of filled grains per panicle and GB-treated plants and SA-treated plants showed $29 \%$ and $44 \%$ decrease in the number of unfilled grains per panicle (Table 3). Plants treated with $\alpha$-tocopherol, GB and SA showed 2\%, 3\% and $2 \%$ decrease in grain length, and $1 \%, 1 \%$ and $1 \%$ increase in grain width, compared to untreated plants (Table 3). There were no significant differences among untreated plants, GB-treated and SA-treated plants with respect to grain chalkiness and grain nitrogen content. However, $\alpha$-tocopherol-treated plants showed $12 \%$ increase in grain chalkiness and 5\% decrease in grain nitrogen content, compared to untreated plants (Table 3).

\section{Discussion}

The present study was conducted to improve our understanding of rice responses to $\alpha$-tocopherol, GB or SA application. Our results indicated beneficial effects of GB $\left(2.0 \mathrm{~kg}\right.$ a.i. ha $\left.{ }^{-1}\right)$ and SA (12.9 g a.i. ha $\left.{ }^{-1}\right)$ application. However, in the present study, application of $\alpha$-tocopherol $\left(2.3 \mathrm{~kg}\right.$ a.i. ha $\left.{ }^{-1}\right)$ at $20 \mathrm{DAE}$ was not beneficial for rice production. The $\alpha$-tocopherol, GB or SA application did not affect production of productive tillers, rice phenology, pollen germination or biomass production. In addition, application of GB decreased plant height. This differs from the findings of Farooq et al., (2008a, b), which state that seed priming of maize (Zea mays L.) with GB or SA increased shoot length, root length and biomass under optimal conditions. Application of $\alpha$-tocopherol, GB or SA did not alter rice phenology. This differs from findings of Oota (1975), and Datta \& Nanda (1985), which state that SA application induces early flowering in duckweeds (Lemna gibba L.) and chenna millet (Panicum miliaceum L.). Salicylic acid induces flowering in plants by acting as a chelating agent (Oota, 1972).

In the present study, GB or SA application did not affect leaf photosynthetic rates or stomatal conductance. In previous studies, plants treated with GB under optimal conditions showed similar results with respect to rice leaf photosynthetic rates and stomatal conductance (Farooq et al., 2008a). Application of SA did not alter leaf photosynthetic rates in mungbean (Vigna radiate L.) plants with respect to leaf photosynthetic rates. However, stomatal conductance decreased with SA application in mungbean (Khan et al., 2010) and corn (Zea mays L.) (Zhou et al., 1999). In the present study, the leaf respiration rate, transpiration rate and relative injury to the leaf membrane decreased with application of $\alpha$-tocopherol, GB or SA. In previous studies, exogenous application of SA had an antitranspiration effect on the leaves of bean (Phaseolus vulgaris L.) and mungbean 
(Larque-Saavedra, 1978; Khan et al., 2010). Moreover, previous studies also suggest the possible roles of $\alpha$-tocopherol, GB and SA in maintaining membrane integrity (Fryer, 1992; Bohnert \& Jensen, 1996; Farooq et al., 2008a, b). In the present study, application of $\alpha$-tocopherol, GB or SA increased membrane stability, which might be due to decreased generation of ROS. The ROS reacts with the proteins, lipids and DNA causing oxidative damage and impairing normal function of the cells (Foyer \& Fletcher, 2001). Increased membrane stability as a result of $\alpha$-tocopherol, GB or SA application decreased respiration rates. Amthor \& McCree (1990) reported that plants increase their maintenance respiration to support repair mechanisms of their damaged membranes as a result of oxidative stress. In the present study, increased membrane integrity was not associated with total antioxidant capacity.

Application of GB or SA did not affect the total number of grains per panicle however did have a profound effect on number of filled grains. Application of SA increases mobilization of reserve food materials to the grain during the grain filling process by increasing the activities of hydrolyzing and oxidative enzymes (Sawhney et al., 1979), hence increasing the number of filled grains. Application of GB increases the synthesis of compatible solutes (Farooq et al., 2008a), whereas application of SA detoxifies superoxide radicals (Bowler et al., 1992), which in turn decreases levels of ROS, thus increasing the integrity of cellular membranes. In addition, GB protects transcriptional and translational machinery, acting as a molecular chaperone in the refolding of enzymes (Rhodes \& Hanson, 1993), whereas SA stabilizes trimers of heat shock transcription factors (Larkindale \& Knight, 2002), thus rendering protection to membranes and enzymes. Decreased respiration rates and increased membrane integrity as a result of GB and SA application might have increased the amount of photosynthates transported to the grains, thereby increasing the number of filled grains per panicle, hence increased spikelet fertility.

In conclusion, yield, the final manifestation of all the physiological processes, increased as a result of GB or SA application under non-stress conditions. In the present study, application of $\alpha$-tocopherol, GB or SA did not affect production of photosynthates, however they decreased consumption of photosynthates and increased membrane stability which might have aided in transport of photosynthates, thereby increasing yield. Decreased membrane stability can disrupt water, ion, and organic-solute movement across plant membranes, thus affecting production, consumption, transport and accumulation of photosynthates (Christiansen, 1978). Moreover, previous studies have also shown a negative association between respiration rates and yield (Lambers, 1985) and a positive association between membrane stability and yield (Ismail \& Hall, 1999). Further field research is required to justify the benefits of these chemical applications for rice farming.

\section{Acknowledgements}

Partial support for this study was generously provided by the Texas Rice Research Foundation and Texas Rice Belt Warehouse. We would also like to thank Dr. Ming-Hsuan Chen, Janis T. Delgado, James Medley and Huma F. Mohammed for their help with various aspects of the grain analyses.

\section{References}

Allakhverdiev, S.I., Feyziev, Y.M., Ahmed, A., Hayashi, H., Aliev, J.A., Kimlov, V.V., Murata, N., \& Carpentier, R. (1996). Stabilization of oxygen evolution and primary electron transport reactions in photosystem II against heat stress with glycinebetaine and sucrose. Journal of Photochemistry and Photobiology, 34, 149-157.

Amthor, J.S., \& McCree, K.J. (1990). Carbon balance of stressed plants: a conceptual model for integrating research results. In: R.G. Alscher \& J.R. Cummings (Eds), Stress responses in plants: adaptation and acclimation mechanisms (pp.1-15). New York: Wiley-Liss.

Ashraf, M., \& Foolad, M.R. (2007). Roles of glycine betaine and proline in improving plant abiotic stress resistance. Environmental and Experimental Botany, 59, 206-216.

Bohnert, H.J., \& Jensen, R.G. (1996). Strategies for engineering water-stress tolerance in plants. Trends in Biotechnology, 14, 89-97.

Bowler, C., Montagu, M.V., \& Inze, D. (1992). Superoxide dismutase and stress tolerance. Annual Review of Plant Physiology and Plant Molecular Biology, 43, 83-116.

Chappelle, E.W., Kim, M.S., \& McMurtrey III, J.E. (1992). Ratio analysis of reflectance spectra (RARS): An algorithm for the remote estimation of the concentration of chlorophyll a, chlorophyll b, and carotenoids in soybean leaves. Remote Sensing of Environment, 39, 239-247.

Christiansen, M.N. (1978). The physiology of plant tolerance to temperature extremes. In: G.A. Jung, (Ed.), Crop tolerance to suboptimal land conditions (pp. 173-191). Madison: ASA. 
Dat, J.F., Lopez-Delgado, H., Foyer, C.H., \& Scott, I.M. (1998). Parallel changes in $\mathrm{H}_{2} \mathrm{O}_{2}$ and catalase during thermotolerance induced by salicylic acid or heat acclimation in mustard seedlings. Plant Physiology, 116, 1351-1357.

Datta, K.S., \& Nanda, K.K. (1985). Effects of phenolic compounds and gibberellic acid on growth and development of cheena millet (Panicum milliaceum L.). Indian Journal of Plant Physiology, 3, 298-302.

Demiral, T., \& Turkman, I. (2004). Does exogenous glycinebetaine affect antioxidative system of rice seedlings under $\mathrm{NaCl}$ treatment? Journal of Plant Physiology, 161, 1089-1100.

Diaz-Zorita, M., Fernandez-Canigia, M.V., \& Grosso, G.A. (2001). Application of foliar fertilizers containing glycinebetaine improved wheat yields. Journal of Agronomy and Crop Science, 186, 209-215.

Farooq, M., Aziz, T., Hussain, M., Rehman, H., Jabran, K., \& Khan, M.B. (2008a). Glycinebetaine improves chilling tolerance in hybrid maize. Journal of Agronomy and Crop Science, 194, 152-160.

Farooq, M., Aziz, T., Basra, S.M.A., Cheema, M.A., \& Rehman, H. (2008b). Chilling tolerance in hybrid maize induced by seed priming with salicylic acid. Journal of Agronomy and Crop Science, 194, 161-168.

Foyer, C.H \& Fletcher, J.M. (2001). Plant antioxidants: colour me healthy. Biologist, 48, 115-120.

Fryer, M.J. (1992). The antioxidant effects of thylakoid vitamin E ( $\alpha$-tocopherol). Plant Cell Environment, 15, 381-392.

Goffman, F.D., \& Bergman, C.J. (2004). Rice kernel phenolic content and its relationship with antiradical efficiency. Journal of the Science of Food and Agriculture, 84, 1235-1240.

Harinasut, P., Tsutsui, K., Takabe, T., Nomura, M., Takabe, T., \& Kishitani, S. (1996). Exogenous glycinebetaine accumulation and increased salt-tolerance in rice seedlings. Bioscience, Biotechnology and Biochemistry, 60, 366-368.

Hayat, S., \& Ahmad, A. (2007). Salicylic Acid - A Plant Hormone. Dordrecht: Springer.

Horváth, E., Pal, M., Szalai, G., Paldi, E., \& Janda, T. (2007). Exogenous 4-hydroxybenzoic acid and salicylic acid modulate the effect of short-term drought and freezing stress on wheat plants. Biologia Plantarum, 51, 480-487.

Hussain, M., Malik, M.A., Farooq, M. Ashraf, M.Y., \& Cheema, M.A. (2008). Improving drought tolerance by exogenous application of glycinebetaine and salicylic acid in sunflower. Journal of Agronomy and Crop Science, 194, 193-199.

Ibrahim, A.M.H., \& Quick, J.S. (2001). Heritability of heat tolerance in winter and spring wheat. Crop Science, 41, 1401-1405.

Ismail, A.M., \& Hall, A.E. (1999). Reproductive-stage heat tolerance, leaf membrane thermostability and plant morphology in cowpea. Crop Science, 39, 1762-1768.

Kawano, T., Sahashi, N., Takahashi, K., Uozumi, N., \& Muto, S. (1998). Salicylic acid induces extracellular superoxide generation followed by an increase in cytosolic calcium ion in tobacco suspension culture: the earliest events in salicylic acid signal transduction. Plant Cell Physiology, 39, 721-730.

Khan, N.A., Syeed, S., Masood, A., Nazar, R., \& Iqbal, N. (2010). Application of salicylic acid increases contents of nutrients and antioxidative metabolism in mungbean and alleviates adverse effects of salinity stress. International Journal of Plant Biology, 1, e1.

Lambers, H. (1985). Respiration in tack plants and tissues: its regulation and dependence on environmental factors, metabolism and invaded organism. In: R. Douce \& D.A. Day (Eds.), Higher plant cell respiration. Encyclopedia of plant physiology (Volume 18). Berlin: Springer-Verlag.

Larkindale, J., \& Huang, B. (2004). Thermotolerance and antioxidant systems in Agrostis stolonifera: Involvement of salicylic acid, abscisic acid, calcium, hydrogen peroxide and ethylene. Journal of Plant Physiology, 161, 405-413.

Larkindale, J., \& Knight, M.R. (2002). Protection against heat stress-induced oxidative damage in Arabidopsis involves calcium, abscisic acid, ethylene, and salicylic acid. Plant Physiology, 128, 682-695.

Larque-Saavedra, A. (1978). The Antitranspirant Effect of Acetylsalicylic Acid on Phaseolus vulgaris. Plant Physiology, 43, 126-128. 
Lichtenthaler, H.K. (1987). Chlorophylls and carotenoids: pigments of photosynthesis, in Methods in Enzymology, 148, 350-352.

Mäkelä, P., Karkkainen, J., \& Somersalo, S. (2000). Effect of glycine betaine on chloroplast ultrastructure, chlorophyll and protein content, and RUBPCO activities in tomato grown under drought or salinity. Biologia Plantarum, 3, 471-475.

Martineau J.R., Specht, J.E., Williams, J.H., \& Sullivan, C.Y. (1979). Temperature tolerance in soybeans. I. Evaluation of a technique for assessing cellular membrane thermostability. Crop Science, 19, 75-78.

Metwally, A., Finkmemeier, I., Georgi, M., \& Dietz, K.J. (2003). Salicylic acid alleviates the cadmium toxicity in barley seedlings. Plant Physiology, 132, 272-281.

Mohammed, A.R., Rounds, E.W., \& Tarpley, L. (2007). Response of rice (Oryza sativa L.) tillering to sub-ambient levels of ultraviolet-B radiation. Journal of Agronomy and Crop Science, 193, 324-335.

Munné-Bosch, S., \& Alegre, L. (2002). The function of tocopherols and tocotrienols in plants. Critical Reviews in Plant Scinces, 21, 31-57.

Munné-Bosch, S., \& Falk, J. (2004). New insights into the function of tocopherols in plants. Planta, 218, 323-326.

Oota, Y. (1975). Short-day flowering of Lemna gibba G3 induced by salicylic acid. Plant Cell Physiology, 16, $1131-1135$.

Paleg, L.G., Douglas, T.J., van Daal, A., \& Keech, D.B. (1981). Proline, betaine and other organic solutes protect enzymes against heat inactivation. Australian Journal of Plant Physiology, 8, 107-114.

Rahman, M.S., Miyake, H., \& Takeoka, Y. (2002). Effects of exogenous glycine betaine on growth and ultrastructure of salt-stressed rice seedlings (Oryza sativa L.). Plant Prod. Science, 5, 33-44.

Rajasekaran, L.R., Kriedemann, P.E., Aspinall, D., \& Paleg, L.G. (1997). Physiological significance of proline and glycinebetaine: maintaining photosynthesis during $\mathrm{NaCl}$ stress in wheat. Photosynthetica, 34, 357-366.

Rao, M.V., Paliyath, G., Ormrod, P., Murr, D.P., \& Watkins, C.B. (1997). Influence of salicylic acid on $\mathrm{H}_{2} \mathrm{O}_{2}$ production, oxidative stress, and $\mathrm{H}_{2} \mathrm{O}_{2}$-metabolizing enzymes. Plant Physiology, 115, 137-149.

Raskin, I. (1992). Role of salicylic acid in plants. Annual Review of Plant Physiology and Plant Molecular Biology, 43, 439-463.

Rhodes, D., \& Hanson, A.D. (1993). Quaternary ammonium and tertiary sulfonium compounds in higher-plants. Annual Review of Plant Physiology and Plant Molecular Biology, 44, 357-384.

Sakhabutdinova, A.R., Fatkhutdinova, D.R., Bezrukova, M.V., \& Shakirova, F.M. (2003). Salicylic acid prevents the damaging action of stress factors on wheat plants. Bulgarian Journal of Plant Physiology, 21, 314-319.

Sawhney, S., Sawhney, N., Kumar, S., \& Nanda, K.K. (1979). Enzyme and electrophoretic pattern of isoenzymes of amylase, catalase, and peroxidase in photo-and gibberellin induced plants of Impatiens balsamina L. New Phytologist, 82, 41-47.

Song, Z.P., Lu, B.R., \& Chen, J.K. (2001). A study of pollen viability and longevity in Oryza rufipogon, O. sativa, and their hybrids. International Rice Research Notes, 26, 31-32.

WeiBing, X., \& Rajashekar, C.B. (2001). Glycine betaine involvement in freezing tolerance and water stress in Arabidopsis thaliana. Environmental and Experimental Botany, 46, 21-28.

Wyn Jones, R.G. (1984). An assessment of quaternary ammounium and related compounds as osmotic effectors in crop plants (photochemical aspects of osmotic adaptation). Recent Advances in Phytochemistry, 18, 55-58.

Yalpani, N., Enyedi, A.J., Leon, J., \& Raskin, I. (1994). Ultraviolet light and ozone stimulate accumulation of salicylic acid, pathogen-related proteins and virus resistance in tobacco. Planta, 193, 372-376.

Zhang, J., \& Kirkham, M.B. (1996). Antioxidant responses to drought in sunflower and sorghum seedlings. New Phytologist, 132, 361-373.

Zhou, X.M., Mackeuzie, A.F., Madramootoo, C.A., \& Smith, D.L.J. (1999). Effects of some injected plant growth regulators, with or without sucrose, on grain production, biomass and photosynthetic activity of field-grown corn plants. Journal of Agronomy and Crop Science, 183, 103-110. 
Table 1. Effects of experiment and chemicals (control, $\alpha$-tocopherol, GB or SA) on rice morphology, phenology and physiology

\begin{tabular}{|c|c|c|c|}
\hline Parameters & Experiments & Chemicals & Experiments $\times$ Chemicals \\
\hline Plant height & NS & $*$ & NS \\
\hline Productive tillers & NS & NS & NS \\
\hline Days for $1^{\text {st }}$ panicle emergence & NS & NS & NS \\
\hline Spikelet fertility & $\mathrm{NS}$ & $* *$ & NS \\
\hline Pollen germination & NS & NS & NS \\
\hline Biomass & NS & NS & NS \\
\hline Yield & NS & $*$ & NS \\
\hline Leaf number per plant & NS & $*$ & NS \\
\hline Leaf length & NS & NS & NS \\
\hline Leaf width & NS & NS & NS \\
\hline Leaf area & NS & $*$ & NS \\
\hline Leaf total chlorophyll content & NS & $*$ & NS \\
\hline Leaf nitrogen content & NS & $*$ & NS \\
\hline Panicle length & NS & NS & NS \\
\hline Number of $1^{\circ}$ branches & NS & NS & NS \\
\hline Total grains per panicle & NS & NS & NS \\
\hline Filled grains per panicle & NS & $*$ & NS \\
\hline Unfilled grains per panicle & NS & $* *$ & NS \\
\hline Grain length & NS & $*$ & NS \\
\hline Grain width & NS & $*$ & NS \\
\hline Grain nitrogen content & NS & $*$ & NS \\
\hline Grain chalkiness & NS & $*$ & NS \\
\hline 100-seed weight & NS & NS & NS \\
\hline Leaf photosynthetic rate & NS & NS & NS \\
\hline Leaf respiration rate & NS & $* * *$ & NS \\
\hline Leaf conductance & NS & NS & NS \\
\hline Leaf internal $\mathrm{CO}_{2}$ & NS & $*$ & NS \\
\hline Leaf transpiration rate & NS & $* *$ & NS \\
\hline Leaf membrane stability & NS & $*$ & NS \\
\hline Leaf total antioxidant capacity & NS & NS & NS \\
\hline Water use efficiency & NS & $*$ & NS \\
\hline
\end{tabular}

$*, * *, * * *$ Significant at the $0.05,0.01$, and 0.001 probability levels respectively.

NS, not significant

Table 2. Effects of $\alpha$-tocopherol, glycine betaine or salicylic acid on morphology, phenology and yield of rice plants

\begin{tabular}{|l|l|l|c|c|}
\hline Parameters & Untreated & $\alpha$-tocopherol & Glycine betaine & Salicylic acid \\
\hline $\begin{array}{l}\text { Plant height }(\mathrm{cm}) \\
(\mathrm{n}=10)\end{array}$ & $94.50 \pm 1.27 \mathrm{a}^{1}$ & $95.10 \pm 1.80 \mathrm{a}$ & $89.40 \pm 2.71 \mathrm{~b}$ & $91.10 \pm 2.20 \mathrm{a}$ \\
\hline $\begin{array}{l}\text { Productive tillers per plant } \\
(\mathrm{n}=10)\end{array}$ & $8.80 \pm 0.56 \mathrm{a}$ & $8.60 \pm 0.64 \mathrm{a}$ & $9.60 \pm 0.36 \mathrm{a}$ & $9.50 \pm 0.45 \mathrm{a}$ \\
\hline $\begin{array}{l}\text { Days for } 1^{\text {st }} \\
\text { panicle emergence }(\mathrm{n}=10)\end{array}$ & $73.00 \pm 0.54 \mathrm{a}$ & $73.00 \pm 0.45 \mathrm{a}$ & $72.70 \pm 0.76 \mathrm{a}$ & $72.70 \pm 0.70 \mathrm{a}$ \\
\hline $\begin{array}{l}\text { Spikelet fertility }(\%) \\
(\mathrm{n}=10)\end{array}$ & $75.53 \pm 4.20 \mathrm{c}$ & $80.15 \pm 2.48 \mathrm{c}$ & $86.02 \pm 1.00 \mathrm{~b}$ & $89.28 \pm 1.03 \mathrm{a}$ \\
\hline $\begin{array}{l}\text { Pollen germination }(\%) \\
(\mathrm{n}=10)\end{array}$ & $30.05 \pm 3.80 \mathrm{a}$ & $26.29 \pm 3.19 \mathrm{a}$ & $30.50 \pm 2.54 \mathrm{a}$ & $26.67 \pm 3.84 \mathrm{a}$ \\
\hline $\begin{array}{l}\text { Biomass per plant }(\mathrm{g}) \\
(\mathrm{n}=10)\end{array}$ & $30.12 \pm 1.11 \mathrm{a}$ & $32.00 \pm 1.64 \mathrm{a}$ & $30.78 \pm 2.02 \mathrm{a}$ & $29.90 \pm 1.07 \mathrm{a}$ \\
\hline $\begin{array}{l}\text { Grain yield per plant }(\mathrm{g}) \\
(\mathrm{n}=10)\end{array}$ & $22.25 \pm 0.86 \mathrm{~b}$ & $23.56 \pm 1.24 \mathrm{ab}$ & $25.14 \pm 1.29 \mathrm{a}$ & $25.26 \pm 0.53 \mathrm{a}$ \\
\hline
\end{tabular}

Each value is the mean with standard error $(\underset{+}{+}$ S.E. $) .{ }^{1}$ Mean values within a row followed by a different letter differed significantly $(\mathrm{P}<0.05)$. 
Table 3. Effects of $\alpha$-tocopherol, glycine betaine or salicylic acid on main-stem panicle and grain (dehulled) characteristics of rice plants

\begin{tabular}{|l|l|l|l|l|}
\hline Parameters & Untreated & $\alpha$-tocopherol & Glycine betaine & Salicylic acid \\
\hline $\begin{array}{l}\text { Panicle length }(\mathrm{cm}) \\
(\mathrm{n}=10)\end{array}$ & $22.66 \pm 0.57 \mathrm{a}^{1}$ & $22.33 \pm 0.50 \mathrm{a}$ & $21.52 \pm 0.41 \mathrm{a}$ & $22.07 \pm 0.52 \mathrm{a}$ \\
\hline $\begin{array}{l}\text { Number of } 1^{\circ} \text { branches per } \\
\text { panicle }(\mathrm{n}=10)\end{array}$ & $14.20 \pm 0.99 \mathrm{a}$ & $14.80 \pm 0.63 \mathrm{a}$ & $13.30 \pm 1.73 \mathrm{a}$ & $15.40 \pm 0.64 \mathrm{a}$ \\
\hline $\begin{array}{l}\text { Total grains per panicle } \\
(\mathrm{n}=10)\end{array}$ & $154.20 \pm 17.92 \mathrm{a}$ & $170.80 \pm 19.91 \mathrm{a}$ & $170.70 \pm 6.92 \mathrm{a}$ & $177.90 \pm 8.66 \mathrm{a}$ \\
\hline $\begin{array}{l}\text { Filled grains per panicle } \\
(\mathrm{n}=10)\end{array}$ & $120.20 \pm 16.72 \mathrm{~b}$ & $139.90 \pm 18.21 \mathrm{ab}$ & $146.50 \pm 5.30 \mathrm{a}$ & $159.00 \pm 8.32 \mathrm{a}$ \\
\hline $\begin{array}{l}\text { Unfilled grains per panicle } \\
(\mathrm{n}=10)\end{array}$ & $34.00 \pm 6.14 \mathrm{a}$ & $30.90 \pm 3.39 \mathrm{a}$ & $24.20 \pm 2.31 \mathrm{~b}$ & $18.90 \pm 1.87 \mathrm{c}$ \\
\hline $\begin{array}{l}\text { Grain length (mm) } \\
(\mathrm{n}=100)\end{array}$ & $7.51 \pm 0.04 \mathrm{a}$ & $7.36 \pm 0.03 \mathrm{~b}$ & $7.29 \pm 0.07 \mathrm{~b}$ & $7.34 \pm 0.03 \mathrm{~b}$ \\
\hline $\begin{array}{l}\text { Grain width (mm) } \\
(\mathrm{n}=100)\end{array}$ & $2.17 \pm 0.01 \mathrm{~b}$ & $2.20 \pm 0.01 \mathrm{a}$ & $2.20 \pm 0.01 \mathrm{a}$ & $2.21 \pm 0.01 \mathrm{a}$ \\
\hline $\begin{array}{l}\text { Grain nitrogen content } \\
\left(\mathrm{mg} \mathrm{g}^{-1}\right)(\mathrm{n}=10)\end{array}$ & $11.06 \pm 0.17 \mathrm{a}$ & $10.54 \pm 0.24 \mathrm{~b}$ & $10.85 \pm 0.16 \mathrm{ab}$ & $11.00 \pm 0.16 \mathrm{a}$ \\
\hline $\begin{array}{l}\text { Grain chalkiness }(\%) \\
(\mathrm{n}=100)\end{array}$ & $25.64 \pm 0.96 \mathrm{~b}$ & $28.77 \pm 0.87 \mathrm{a}$ & $26.03 \pm 0.88 \mathrm{~b}$ & $27.15 \pm 0.83 \mathrm{ab}$ \\
\hline $\begin{array}{l}100 \text {-seed weight }(\mathrm{g}) \\
(\mathrm{n}=10)\end{array}$ & $2.7 \pm 0.4 \mathrm{a}$ & $2.3 \pm 0.1 \mathrm{a}$ & $2.2 \pm 0.2 \mathrm{a}$ & $2.3 \pm 0.1 \mathrm{a}$ \\
\hline
\end{tabular}

Each value is the mean with standard error $(+$ S.E. $) .{ }^{1}$ Mean values within a row followed by a different letter differed significantly $(\mathrm{P}<0.05)$.

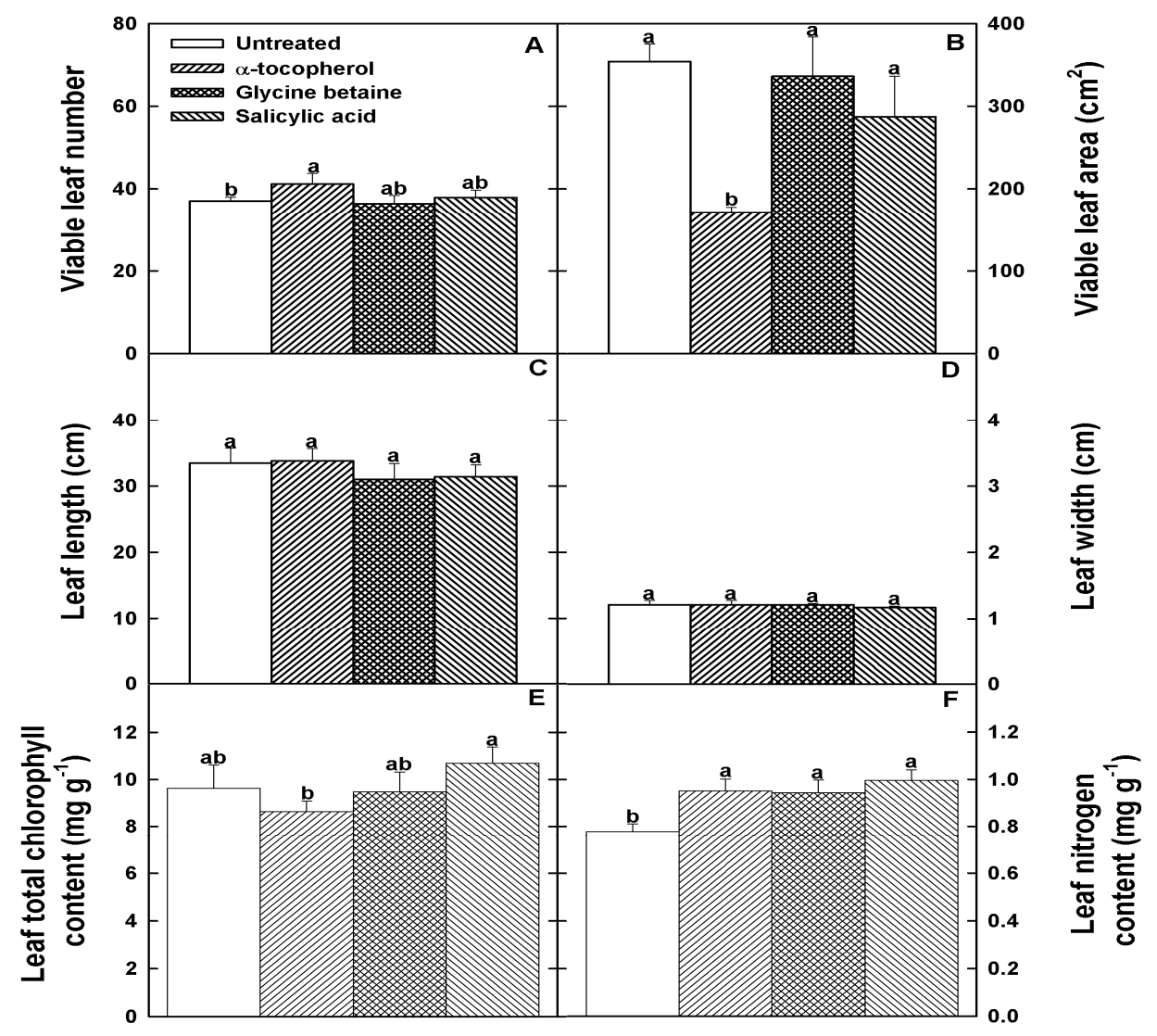

Figure 1. Effects of $\alpha$-tocopherol, glycine betaine or salicylic acid on rice leaf characteristics. Bars with different letters for a particular parameter differed significantly at $\mathrm{P} \leq 0.05$ 


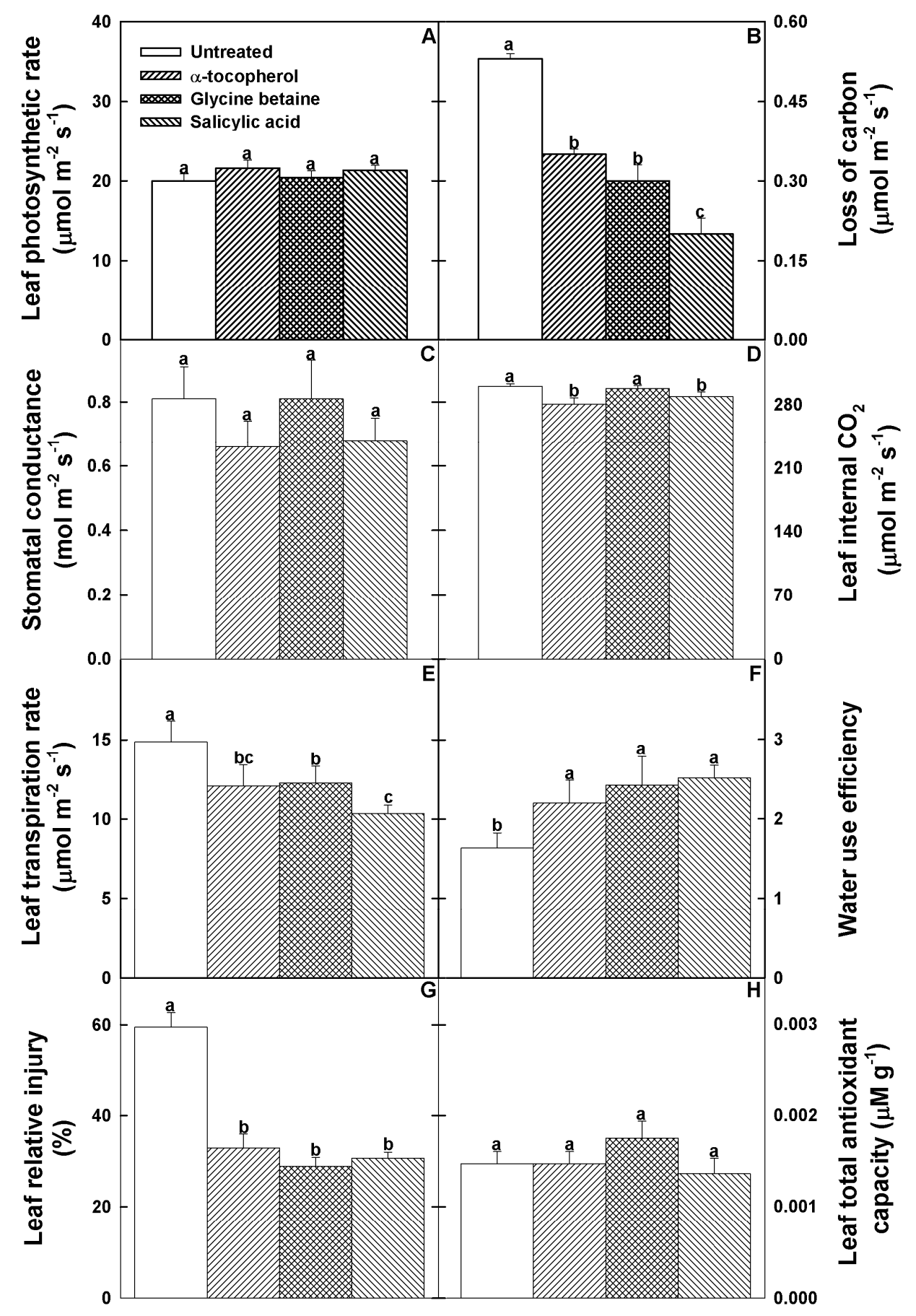

Figure 2. Effects of $\alpha$-tocopherol, glycine betaine or salicylic acid on rice leaf physiology. Bars with different letters for a particular parameter differed significantly at $\mathrm{P} \leq 0.05$ 